\title{
Effects of cadmium on some haematological and biochemical parameters of Clarias graiepinus
}

\author{
Naglaa F. Elarabany ${ }^{1}$, Mohammed H. Bahnsawy ${ }^{1}$ and Mona Alfakheri ${ }^{1,2}$ \\ 1- Zoology Department, Faculty of Science, Damietta Univ., Damietta, 34514, Egypt \\ 2- Zoology Department, Faculty of Science, Sabha Univ., Sabha, Libya \\ elarabany@du.edu.eg
}

\begin{abstract}
This study aimed to determine the effects of sub-lethal concentrations of cadmium $\left(\mathrm{CdCl}_{2}\right)$ on some haematological and biochemical parameters in 172 specimens of Clarias gariepinus. Fishes were captured from Manzala Lake, Egypt. They were acclimatized and fed with commercial fish diet for one month before starting the experiment. After determination of LC50, Two experimental groups were exposed to two sub-lethal concentrations $(10 \%$ and $30 \%$ of $\mathrm{LC}_{50}$ ) of cadmium chloride along with control group. Fishes from different experimental groups were sacrificed after 60 days of exposure. Haematological parameters including erythrocytes, $\mathrm{Hb}, \mathrm{PCV}$, thrombocyte, leucocytes, and differential count of WBCs were estimated. Also, some biochemical parameters such as sodium, potassium, calcium, glucose, total protein, albumin, AST, ALT, ammonia, urea, uric acid, total bilirubin, creatinine, total lipids, cholesterol, triglycerides and cortisol and oxidative stress enzymes such as GSH, CAT, SOD, and MDA were measured. Group treated with $10 \%$ of $\mathrm{LC}_{50}$ of $\mathrm{Cd}$ showed significantly lower concentrations of $\mathrm{Hb}$, thrombocytes and SOD activity and significantly higher concentrations of eosinophil, MDA, and triglyceride. On the other hand, group of $30 \mathrm{LC}_{50}$ of $\mathrm{Cd}$ showed a significantly lower concentration of sodium and significantly higher activities of CAT, ALT and ammonia concentrations. The investigated two sub-lethal concentration ( $10 \%$ and $30 \%$ of $\mathrm{LC}_{50}$ of $\mathrm{Cd}$ ) groups showed a significantly lower activity of GSH and lower concentrations of potassium and cholesterol, besides these showed a significantly higher concentrations of uric acid and creatinine. Serum calcium, glucose, albumin, AST, urea and total lipids did not show any significant differences in the estimated treatment concentrations.
\end{abstract}

Key words: Cadmium, oxidative stress, haematotoxicity, African catfish, Clarias gariepinus.

\section{INTRODUCTION}

Heavy metals generally have different effects on fishes depending on the type of heavy metal, its concentration in water and the period of exposure (Boscher et al., 2010). Many studies have shown that bioaccumulation of heavy metals affects fish growth rate and the quality of their meat, beside to its significant effect on fish physiological and chemical status (Soegianto et al., 2010). Some heavy metals are essential in the environment system such as copper, chromium, and iron, while others such as cadmium and lead are not necessary and are toxic even in low concentrations (Rubio et al., 2016).
Cadmium is a highly toxic heavy metal, produced from liquid waste, paint, and mining extracts (Perez and Wallace, 2004). Studies showed that fish exposed to different concentrations of cadmium can be found at different rates in some organs such as liver, kidneys, and gills (Klinck et al., 2007), however, exposure to this metal causes changes in metabolism as well as many biochemical and physiological effects (Szebedinszky et al., 2001). Fishes convert the foreign compounds enzymatically into less harmful compounds, reactions are often the most important processes xenobiotic biotransformation (Persch et al., 2017). 


\section{Naglaa F. Elarabany et al.}

Clarias gariepinus, the African catfish, has a great nutritional importance as an economical source of protein in Egypt, being one of the most common freshwater fish, therefore it's a good animal model for investigating the impact of various environmental pollutants (Darwin et al., 2017). This species is resistant to environmental stress and can adapt to different types of food in the environment and it can be available at night or day (Qu et al., 2014).

Exposure to cadmium leads to accumulation in fish tissue, later, many serious disorders appear in the metabolism, behavior change, abnormalities in movement, and obvious effects on blood (Gabriel et al., 2004). Joshp et al. (2002) studied the effect of cadmium on catfish Clarias batrachus and their results showed that $\mathrm{Cd}$ caused a reduction in hemoglobin and erythrocytes count and glucose, cholesterol, and protein levels. Also, Cd decreased MCHC and PCV in Heterobranchus bidorsalis (Kori-Siakpere et al., 2006). This metal had been proved to lower GSH activity (Amaeze et al., 2015).

Due to the lack of studies on African catfish and its economic importance as food source in Egypt, this study aimed to measure the changes of haematological, biochemical parameters and oxidative stress enzymes in this fish after its exposure for 60 days to two different doses of of $\mathrm{LC}_{50}$ of cadmium chloride.

\section{MATERIALS AND METHODS 1 Determination of $\mathrm{LC}_{50}$}

One hundred and seventy-two African catfish, Clarias gariepinus (mean body weight is $150 \pm 25 \mathrm{~g}$ ) were obtained from Manzala Lake, Damietta, Egypt. Fishes, apparently healthy, were transported immediately to the lab and acclimatized for two weeks in glass aquaria $(40 * 35 * 70 \mathrm{~cm})$ with a capacity of $60 \mathrm{~L}$ and were fed on a basal fish diet.
After acclimation, 100 fishes were divided into ten groups (10 fishes/ group) for determination of $\mathrm{LC}_{50}$, each group was exposed to a different concentrations of $\mathrm{CdCl}_{2}(10 \mathrm{mg} / \mathrm{l}, 20 \mathrm{mg} / \mathrm{l}, 30 \mathrm{mg} / \mathrm{l}, 40$ $\mathrm{mg} / \mathrm{l}, 50 \mathrm{mg} / \mathrm{l}, 60 \mathrm{mg} / \mathrm{l}, 70 \mathrm{mg} / \mathrm{l}, 80 \mathrm{mg} / \mathrm{l}$,) at constant temperature $25^{\circ} \mathrm{C}$. Fishes were kept under observation for 96 hours and numbers of dead fishes were recorded daily. The $\mathrm{LC}_{50}$ was statistically determined by using dose-effect analysis using XLSTAT software.

\section{Experimental fishes model:}

After determination of $\mathrm{LC}_{50}, 72$ fishes were divided randomly into equal three groups with 8 fishes in all aquaria, each group was represented by triplets ( 24 fishes for each treatment); Control, $\mathrm{Cd}$ $10 \%$ of $\mathrm{LC}_{50}$ and $\mathrm{Cd} 30 \%$ of $\mathrm{LC}_{50}$ for 60 days.

\section{Test Compound}

Cadmium as $\mathrm{CdCl}_{2} \cdot \mathrm{H}_{2} \mathrm{O}$ (monohydrate, molecular weight $201.32 \mathrm{~g}$, purity $98 \%$ ), manufactured by Oxford Lab Chem, India.

\section{Blood sampling}

Fishes fasted for 24 hours before sampling; blood samples were obtained from the caudal vein using $3 \mathrm{ml}$ syringe within less than 3 minutes to minimize handling stress. The collected blood samples were divided into two tubes, one containing heparin as anticoagulant agent for haematological assessment and the other was anticoagulant free for biochemical estimation.

Haematological measurements were assayed within one hour of sampling using blood cell automated counter. Red blood cells count (RBCs), haemoglobin content $(\mathrm{Hb})$, thrombocytes count (TC), and white blood cells count (WBCs) were evaluated. Different blood indices such as mean corpuscular volume (MCV), mean corpuscular haemoglobin $(\mathrm{MCH})$ and 


\section{Effects of cadmium on some haematological and biochemical parameters of Clarias graiepinus}

mean corpuscular hemoglobin concentration (MCHC) were calculated.

Anticoagulant free samples were used for serum preparation by centrifugation for 20 minutes at $1207 \mathrm{~g}$ within one hour of sampling, the sera samples were used for determination of malondialdehyde (MDA), Catalase (CAT), Sodium $\left(\mathrm{Na}^{+}\right)$, Potassium $\left(\mathrm{K}^{+}\right)$, Calcium (Ca), Glucose (GLU), Total protein (TP), Albumin (ALB), Glutamic - Oxaloacetic Transaminase (AST), Glutamic - Pyruvic Transaminase (ALT), Ammonia (AMM), Urea (UREA), Uric Acid (UR AC), Total Bilirubin (TB), Creatinine,(CREA), Total lipids (TL), Cholesterol(CHOL), Triglycerides(TRI)and Cortisol (COR), while superoxide dismutase (SOD) was determined in RBCs lysate later on the same day with commercial kits. Absorbance values of samples and standards were measured using a UV spectrophotometer.

\section{Statistical analysis}

Data were expressed as mean \pm SEM of different treated groups compared to control ones. Normal distribution of all parameters was tested. The results were analyzed using one-way analysis of variance (ANOVA) followed by Tukey (HSD) test to compare groups with each other and Dennett two-sided test for comparisons with the control group. $P<0.05$ was considered significant. All statistical analyses were performed using XLSTAT program.

\section{RESULTS}

As shown in Table (1), $\mathrm{Hb}$ and TC were significantly lower in $\mathrm{Cd} 10 \%$ group compared to control group. On the other hand, MCV was significantly lower in control group compared with $\mathrm{Cd} 10 \%$ and $\mathrm{Cd} 30 \%$ group. Eosinophils also were significantly higher in $\mathrm{Cd} 10 \%$ group compared to control group. For other haematological parameters no significant changes were found between different groups.

Glutathione reduced (GSH) concentration was significantly lower in $\mathrm{Cd} \mathrm{10 \%}$ and $\mathrm{Cd} 30 \%$ groups compared to control group. On the other hand catalase (CAT) activity was significantly higher in Cd 30\% group compared to control group.

Lipid peroxide product (Malondialdehyde, MDA) was significantly higher in $\mathrm{Cd} 10 \%$ group compared to control group, while superoxide dismutase (SOD) activity was significantly lower in $\mathrm{Cd} 10 \%$ group compared to control group.

Table 1: Means \pm SEM of haematological parameters of African catfish, clarias gariepinus treated with different $\mathrm{Cd}$ concentrations $\left(10 \%, 30 \% \mathrm{LC}_{50}\right)$ for 60 days.

\begin{tabular}{|c|c|c|c|c|}
\hline \multirow{2}{*}{ Parameter } & \multicolumn{3}{|l|}{ Groups } & \multirow[b]{2}{*}{$\mathrm{P}$} \\
\hline & Control & $\mathrm{Cd} \mathbf{1 0 \%} \mathbf{L C}_{50}$ & $\mathrm{Cd} \mathbf{3 0} \% \mathbf{L C}_{50}$ & \\
\hline $\operatorname{PCV}(\%)$ & $29.43 \pm 0.57$ & $29.33 \pm 0.83$ & $29.11 \pm 0.45$ & NS \\
\hline $\mathrm{Hb}(\mathrm{g} / \mathrm{dl})$ & $11.97 \pm 0.48^{\mathrm{a}}$ & $10.35 \pm 0.28^{b}$ & $10.88 \pm 0.56^{\mathrm{a}}$ & 0.01 \\
\hline $\operatorname{MCV}(f l)$ & $81.90 \pm 2.61^{\mathrm{a}}$ & $90.39 \pm 2.50^{b}$ & $87.47 \pm 3.11^{b}$ & 0.01 \\
\hline $\mathrm{MCH}(\mathrm{Pg})$ & $31.24 \pm 0.56$ & $31.6 \pm 0.75$ & $32.37 \pm 1$ & NS \\
\hline $\mathrm{MCHC}(\mathrm{g} / \mathrm{dl})$ & $38.91 \pm 1.01$ & $35.15 \pm 0.95$ & $37.13 \pm 1.66$ & NS \\
\hline Erythrocytes $\left(10^{6} / \mu 1\right)$ & $3.77 \pm 0.14$ & $3.28 \pm 0.09$ & $3.37 \pm 0.14$ & NS \\
\hline Thrombocytes $\left(10^{3} / \mu 1\right)$ & $62.43 \pm 12.8^{a}$ & $52.75 \pm 9.2^{b}$ & $61.89 \pm 14.8^{\mathrm{a}}$ & 0.04 \\
\hline Leucocytes $\left(10^{3} / \mu \mathrm{l}\right)$ & $3.40 \pm 0.23$ & $3.78 \pm 0.15$ & $3.57 \pm 0.32$ & NS \\
\hline Neutrophils (\%) & $7 \pm 0.58$ & $6.33 \pm 1.21$ & $6.56 \pm 1.08$ & NS \\
\hline Eosinophil (\%) & $2.57 \pm 0.20^{a}$ & $3.17 \pm 0.21^{b}$ & $2.89 \pm 0.39^{\mathrm{a}}$ & 0.01 \\
\hline Lymphocyte (\%) & $86 \pm 0.76$ & $83.50 \pm 0.89$ & $85.11 \pm 1.26$ & NS \\
\hline
\end{tabular}

Values different superscript letters within each row are significantly different $(P<0.05)$. 


\section{Naglaa F. Elarabany et al.}

As shown in Table (2) there were significant lower in $\mathrm{Cd} 10 \%$ and $\mathrm{Cd} 30 \%$ groups comparing to control group in potassium, total protein, and cholesterol, while $\mathrm{Cd} 30 \%$ group was significantly lower than control group in sodium. On the other hand, $\mathrm{Cd} \mathrm{30 \%} \mathrm{group} \mathrm{was}$ significantly higher in ALT, ammonia and cholesterol level comparing to control group but in triglycerides, Cd10 \% group was higher than control group, while $\mathrm{Cd}$
$10 \%$ and $\mathrm{Cd} 30 \%$ groups were significantly higher comparing to control group in both uric acid and creatinine.

No significant differences were found between different concentrations of treated and control groups in other parameters such as calcium, glucose, albumin, AST, urea and total lipids (Table $3)$.

Table 2: Means \pm SEM of Lipid peroxidation and oxidative system of African catfish, Clarias gariepinus treated with different $\mathrm{Cd}$ concentrations $\left(\mathbf{1 0 \%}, \mathbf{3 0 \%} \mathrm{LC}_{50}\right)$ for 60 days.

\begin{tabular}{|c|c|c|c|c|}
\hline \multirow{2}{*}{ Parameter } & \multicolumn{3}{|l|}{ Groups } & \multirow[b]{2}{*}{$\mathbf{P}$} \\
\hline & Control & Cd $10 \%$ of $\mathrm{LC}_{50}$ & Cd $30 \%$ of $\mathrm{LC}_{50}$ & \\
\hline GSH(U/L) & $15.69 \pm 1.59^{\mathrm{a}}$ & $10.65 \pm 0.60^{b}$ & $11.19 \pm 0.96^{\mathrm{b}}$ & 0.041 \\
\hline CAT (U/l) & $86.98 \pm 29.19^{a}$ & $97.61 \pm 20.59^{\mathrm{a}}$ & $206.62 \pm 27.38^{b}$ & 0.015 \\
\hline $\operatorname{MDA}(\mathrm{nmol} / \mathrm{ml})$ & $40.89 \pm 5.49^{a}$ & $45.32 \pm 6.91^{b}$ & $39.60 \pm 3.29^{\mathrm{a}}$ & 0.009 \\
\hline SOD (U/gm) & $267.18 \pm 527.9^{a}$ & $197.84 \pm 191.8^{b}$ & $233.33 \pm 350.5^{a b}$ & 0.018 \\
\hline
\end{tabular}

Values different superscript letters within each row are significantly different $(P<0.05)$.

Table 3: Means \pm SEM of biochemical parameters of Catfish Clarias gariepinus treated with different $\mathrm{Cd}(10 \%, 30 \%)$ for 60 days.

\begin{tabular}{|c|c|c|c|c|}
\hline \multirow{2}{*}{ Parameter } & \multicolumn{4}{|l|}{ Groups } \\
\hline & Control & $\mathrm{Cd} 10 \%$ of $\mathrm{LC}_{50}$ & Cd $30 \%$ of $\mathrm{LC}_{50}$ & $\mathbf{P}$ \\
\hline Sodium (mEq/L) & $228.3 \pm 10.8^{a}$ & $199.2 \pm 4.4^{\mathrm{ab}}$ & $183.2 \pm 7.19^{b}$ & 0.008 \\
\hline Potassium (mEq/L) & $4.21 \pm 0.21^{\mathrm{a}}$ & $3.92 \pm 0.12^{b}$ & $3.95 \pm 0.18^{b}$ & 0.08 \\
\hline Calcium(mg/dl) & $11.29 \pm 0.10$ & $11.41 \pm 0.17$ & $11.22 \pm 0.31$ & NS \\
\hline Glucose (mg/dl) & $51.6 \pm 3.03$ & $54.41 \pm 3.80$ & $58.23 \pm 4.69$ & NS \\
\hline T. protein $(\mathrm{g} / \mathrm{dl})$ & $5.75 \pm 0.23^{\mathrm{a}}$ & $4.79 \pm 0.31^{b}$ & $4.25 \pm 0.24^{b}$ & 0.001 \\
\hline Albumin(g/dl) & $2.47 \pm 0.08$ & $2.68 \pm 0.10$ & $2.51 \pm 0.06$ & NS \\
\hline $\mathrm{AST}(\mathrm{g} / \mathrm{dl})$ & $35.83 \pm 7.35$ & $37.3 \pm 8.02$ & $39.6 \pm 12.23$ & NS \\
\hline $\mathrm{ALT}(\mathrm{g} / \mathrm{dl})$ & $16.20 \pm 2.13^{a}$ & $17.11 \pm 2.25^{\mathrm{a}}$ & $18.00 \pm 1.59^{b}$ & 0.0006 \\
\hline Ammonia(mg/dl) & $164.1 \pm 13.5^{\mathrm{a}}$ & $242.2 \pm 7.9^{\mathrm{ab}}$ & $266.3 \pm 25.4^{b}$ & 0.008 \\
\hline $\operatorname{Urea}(\mathrm{mg} / \mathrm{dl})$ & $8.30 \pm 0.22$ & $9.43 \pm 0.40$ & $8.14 \pm 0.52$ & NS \\
\hline Uric Acid(mg/dl) & $3.46 \pm 0.33^{\mathrm{a}}$ & $10.58 \pm 1.1^{b}$ & $9.49 \pm 1.25^{b}$ & 0.0001 \\
\hline Bilirubin(mg/dl) & $1.34 \pm 0.0^{\mathrm{a}}$ & $2.09 \pm 0.19^{b}$ & $2.09 \pm 0.25^{b}$ & 0.0004 \\
\hline Creatinine(mg/dl) & $0.18 \pm 0.04^{\mathrm{a}}$ & $0.26 \pm 0.06^{b}$ & $0.31 \pm 0.05^{b}$ & 0.03 \\
\hline T. lipids(mg/dl) & $765.9 \pm 51.2$ & $572.5 \pm 68.25$ & $607.4 \pm 52.09$ & NS \\
\hline Cholesterol(mg/dl) & $455.9 \pm 38.5^{\mathrm{a}}$ & $308.7 \pm 28.0^{b}$ & $211.1 \pm 18.8^{b}$ & 0.03 \\
\hline Triglycerides(mg/dl) & $240 \pm 13.78^{a}$ & $406.4 \pm 69.6^{b}$ & $237.7 \pm 31.1^{\mathrm{a}}$ & 0.02 \\
\hline Cortisol (ng/ml)) & $100 \pm 6.7^{\mathrm{a}}$ & $278.9 \pm 102.9^{a}$ & $718 \pm 84.0^{b}$ & 0.0001 \\
\hline
\end{tabular}

Values with different superscript letters within each row are significantly different $(P<0.05)$.

\section{DISCUSSION}

\section{Haematological parameters:}

In the current study, $\mathrm{Hb}$ and thrombocytes were significantly lower in $\mathrm{Cd} 10 \%$ and $\mathrm{Cd} 30 \%$ groups compared to control group, while eosinophil was significantly higher $\mathrm{Cd} 10 \%$ compared to control group and MCV was significantly higher in $\mathrm{Cd} 10 \%$ and $\mathrm{Cd} 30 \%$ groups comparing to control. Similar results were 


\section{Effects of cadmium on some haematological and biochemical parameters of Clarias graiepinus}

reported by where there were increase in $\mathrm{Hb}$ and thrombocytes and decrease in MCV and eosinophil after exposure to cadmium. This changes may be due to the defects that occurred in both hemopoietic and metabolic states of the treated fishes where exposure to Sublethal concentrations of $\mathrm{Cd}$ cause hemopoietic organs dysfunction resulting in low $\mathrm{Hb}$ concentrations due to destructive effect of Cd (Sharma and Langer, 2014).

\section{Oxidative Stress Enzymes}

In the present study, GSH concentration was significantly lower in $\mathrm{Cd} 10 \%$ and $\mathrm{Cd} 30 \%$, respectively, compared to the control group. Similar results were found in Clarias graiepinus where GSH concentration decreased after 21 days of exposure to different concentrations of cadmium (Amaeze et al., 2015). Oxidative stress may be initiated by a decline in the antioxidative defense system, GSH loss in fishes reflects the ability of metals in oxidizing sulfhydryl group resulting in inactivation of oxidative enzymes by free radicals.

CAT activity increased in $\mathrm{Cd} 30 \%$ compared to the control group. Some investigators have suggested that severe oxidative stress may suppress the activity of antioxidant defense enzymes due to oxidative damage and a loss of the compensatory mechanisms (Atli et al., 2006; Liu et al., 2006). Similar results on Clarias graiepinus, showed that cadmium increased CAT activity (Bakare et al., 2013). This increase in CAT activity is due to the degradation of $\mathrm{H}_{2} \mathrm{O}_{2}$, a potent oxidant at high cellular concentration is affected by CAT due to its induction against increased oxidative stress.

MDA, is used as an effective biomarker of toxic pollutants in fish exposed to cadmium, MDA level, in the current study, increased in Cd 10\% group compared to the control group. Similar results were found in Clarias graiepinus where MDA level increased after exposure to varying concentrations of cadmium 'Farombi et al., 2007), the production of MDA is a marker of lipid peroxidation results from the decomposition of polyunsaturated fatty acid due to oxidative stress (Alfanie et al., 2015). SOD activity decreased significantly in $\mathrm{Cd} 10 \%$ compared to the control group and then increased in $\mathrm{Cd} 30 \%$ group. This pattern of change was found in similar results were found in Clarias graiepinus where SOD activity decreased after exposure to cadmium and increased near to control values (Asagba $e t$ al., 2010), these pattern indicate the activation of protective mechanisms required for removing O2- radical in RBCs (Zikić et al., 2001).

\section{Biochemical parameters:}

In the current work, sodium level reduced significantly in Cd 30\% compared to the control group. Similar results were found in Clarias graiepinus where sodium level decreased in African catfish after exposure to $10 \mathrm{mg} / \mathrm{L}$ cadmium (El-Boshy et al., 2014a). Similarly, potassium level reduced in $\mathrm{Cd} 10 \%$ and $\mathrm{Cd} 30 \%$ compared to the control group. Similar result was found in Clarias graiepinus where exposure to cadmium reduced potassium level (El-Boshy et al., 2014a).

Since freshwater fish are hyperosmotic to the surrounding water, disruption of the gill epithelium that occurs after long-term metal exposures will increase epithelium permeability, water influx, and salt efflux (Kamunde et al., 2002), and thus lead to a final significant decrease in plasma osmolality and ion concentrations such as $\mathrm{Na}^{+}$and $\mathrm{K}^{+}$ (Monteiro et al., 2005).

The Total protein level, in the current study, increased in both $\mathrm{Cd} 10 \%$ and $\mathrm{Cd} 30 \%$ compared to the control group. Similar results were found in Clarias graiepinus where total protein level elevated with the presence of high concentrations of cadmium (Gaber et al., 


\section{Naglaa F. Elarabany et al.}

2013). On contrary, , the exposure to 0.5 $\mathrm{mg} \mathrm{Cd}^{1-}$ and $1.0 \mathrm{mg} \mathrm{Cd}^{1-}$ recorded a significant decrease in the level of protein in Clarias graiepinus (Kori-Siakpere et al., 2006). Moreover, Clarias batrachus exposed to $1 \mathrm{mg}$ of $\mathrm{CdSO}_{4}$ for 32 days, showed a significant reduction in protein levels (Kumar, 2016). Hyperproteinnemia observed in the study groups may be due to liver or kidney damage (El-Boshy et al., 2014b).

The current results showed a significant increase of ALT activity in fishes treated with $30 \% \mathrm{Cd}$. A similar result was found in Clarias graiepinus where ALT activity was higher after exposure to cadmium (El-Boshy et al., 2014a). This elevation may reflect hepatocytes damage.

Ammonia level increased Cd $30 \%$ compared to the control group. In the same line, Clarias graiepinus showed a high level of ammonia in study areas that contained a high concentration of cadmium (Gaber et al., 2013). In another study on the Nile River region from Aswan to Damietta, the concentration of cadmium was at the highest level and above the permissible limit in catfish Clarias graiepinus, and ammonia level was very high on the studied fish (Osman and Kloas, 2010). An increase in ammonia production may be a result of metalinduced stress together with an impaired ability to excrete ammonia across the gill which is the typical response to metal exposure in freshwater fish and leads to elevated plasma ammonia levels (Grosell et al., 2004; Patra et al., 2015).

The uric acid level, in the current study, increased in both $\mathrm{Cd} 10 \%$ and $\mathrm{Cd}$ $30 \%$, compared to the control group. Similar results were found in Clarias graiepinus exposed to $10 \mathrm{mg} / \mathrm{L}$ cadmium where uric acid level was higher than the control group (El-Boshy et al., 2014a). This increase in uric acid concentration could be attributed to the action of accumulated recorded pollutants on the glomerular filtration rate, which caused pathological changes in the kidney. These results may be also supported by the findings that exposure of fish to high concentrations of heavy metals led to the disintegration of the renal epithelial cells, displacement of nuclei, shrinkage of glomeruli, breakdown of Bowman's capsules and heavy infiltration by inflammatory cells (Authman and ElSehamy, 2007).

In the current study, bilirubin increased in $\mathrm{Cd} 10 \%$ and $\mathrm{Cd} 30 \%$ compared to the control group. A similar result was found in Clarias batrachus where bilirubin was higher due to the effect of $1 / 10^{\text {th }}$ of $\mathrm{LC}_{50}$ cadmium treatment for 4 days. The elevated levels of bilirubin may indicate liver impairment and destruction of RBCs due to cadmium toxicity (Harabawy and Ibrahim, 2014).

Similarly, creatinine level increased in $\mathrm{Cd} 10 \%$ and $\mathrm{Cd} 30 \%$ groups compared to the control one. Similarly, Clarias batrachu exhibited elevated creatinine levels when exposed to $2.5 \mathrm{ppm}$ cadmium, this elevated creatinine levels may indicate that cadmium is a nephrotoxic metal to fishes which cause kidney dysfunction..

Cholesterol level, in the current study, decreased in $\mathrm{Cd} 10 \%$ and $\mathrm{Cd} 30 \%$ compared to the control group. Similar results were found with Clarias garaiepinus that maintained in cadmiumcontaminated water for a period of 14 days (Samuel et al., 2017). Also, Clarias batrachus showed decreased level of cholesterol after exposure to $1 \mathrm{mg} / \mathrm{l}$ of $\mathrm{CdSO}_{4}$ compared to the control group (Kumar, 2016). This alteration in cholesterol concentration could be due to hazardous effects of metals on the cell membrane or may be attributed to an increase in lipid utilization for meeting additional energy requirements under stress conditions (Sindhe et al., 2002; Srivastava et al., 2002). 


\section{Effects of cadmium on some haematological and biochemical parameters of Clarias graiepinus}

Triglycerides level increased in Cd10\% group compared to the control group. These results in line with those of Clarias batrachus that exposed to different doses of cadmium $(0,70.0,75.0,82.5$, 92.5 and $95.0 \mathrm{mg} / \mathrm{l})$ (Dhara et al., 2014). There are a number of reports indicating that cadmium influence thyroid function. Since decreases thyroid secretion (hypothyroidism) greatly increases triglycerides level in the blood, the observed hypertriglyceridemia may due to hypothyroidism induced by cadmium and/ or liver dysfunction because the liver is the principal center of lipid metabolism (Gaber et al., 2013)

Cortisol level increased in $\mathrm{Cd} 30 \%$ compared to the control group. Similar results were found in Clarias graiepinus where cortisol level increased significantly after exposure to 0.25 and $0.50 \mathrm{ppm}$ cadmium (Karaytug et al., 2010). Stress factors such as exposure to cadmium affect cortisol concentration in fishes, hormonal response is the 1 st response to varying environmental condition, cortisol is a key hormone in maintaining homeostatis (Karaytug et al., 2010).

\section{Conclusion}

This study shows that different concentration of $\mathrm{Cd}$ leads to stress in the metabolic and antioxidant enzyme activities and other biomarkers of oxidative stress in Clarias gariepinus which may cause biochemical dysfunction in this species. In addition, the results provide evidence that enzymatic and nonenzymatic biomarkers of oxidative stress can be used as sensitive indicators of aquatic pollution.

\section{REFERENCES}

Alfanie, I.; Muhyi, R. and Suhartono, E. (2015). Effect of Heavy Metal on Malondialdehyde and Advanced Oxidation Protein Products Cencentration A Focus on Arsenic, Cadmium, and Mercury. J. Med. and Bioengineering Vol 4.
Amaeze, N.H.; Adeyemi, R.O. and Adebesin, A.O. (2015). Oxidative stress, heats shock protein and histopathological effects in the gills of African catfish, Clarias gariepinus induced by bridge runoffs. Environ. Monitoring and Aassessment, 187: 172.

Asagba, S.; Eriyamremu, G.; Emudainohwo, J. and Okoro, I. (2010). Oxidative enzymes in tissues of the catfish (Clarias gariepinus) exposed to varying levels of cadmium. The Environmentalist, 30: 260-266.

Atli, G.; Alptekin, Ö.; Tükel, S. and Canli, M. (2006). Response of catalase activity to $\mathrm{Ag}+, \mathrm{Cd} 2+, \mathrm{Cr} 6+, \mathrm{Cu} 2+$ and $\mathrm{Zn2}+$ in five tissues of freshwater fish Oreochromis niloticus. Comparative Biochemistry and Physiology Part C: Toxicology \& Pharmacology, 143: 218-224.

Authman, M. and El-Sehamy, M. (2007). Pesticides residues in water and fish collected from Kafr Al-Zayat pesticide factory zone and their impact on human health. Egypt. J. Zool., 48: 257-282.

Bakare, A.A.; Alabi, O.A.; Gbadebo, A.M.; Ogunsuyi, O.I. and Alimba, C.G. (2013). In vivo cytogenotoxicity and oxidative stress induced by electronic waste leachate and contaminated well water. Challenges, 4: 169-187.

Boscher, A.; Gobert, S.; Guignard, C.; Ziebel, J.; L'Hoste, L.; Gutleb, A.C.; Cauchie, H.M.; Hoffmann, L.; Schmidt, G. (2010). Chemical contaminants in fish species from rivers in the North of Luxembourg: Potential impact on the Eurasian otter (Lutra lutra). Chemosphere, 78: 785-792.

Darwin, D.; Sarbaini, S.; Purwanto, S.; Dhiauddin, F.; Ilham, M. and Fazil, A. (2017). Wastewater treatment 


\section{Naglaa F. Elarabany et al.}

for African Catfish (Clarias gariepinus) Culture by Using Anaerobic Process. Agritech, 37: 462-470.

El-Boshy, M.E.-S.; Gadalla, H.A. and ElHamied, F.M.A. (2014a). Immunological, hematological and biochemical changes induced by short term exposure to cadmium in catfish (Clarias gariepinus). J. Coastal Life Med., 2: 175-180.

El-Boshy, M.E.-S.; Gadalla, H.A. and ElHamied, F.M.A. (2014b). Immunological, hematological and biochemical changes induced by short term exposure to cadmium in catfish (Clarias gariepinus). J. Coast. Life Med., 2: 175-180.

Farombi, E.; Adelowo, O. and Ajimoko, Y. (2007). Biomarkers of oxidative stress and heavy metal levels as indicators of environmental pollution in African cat fish (Clarias gariepinus) from Nigeria Ogun River. Int. J. Environ. Res. Public Health, 4: 158-165.

Gaber, H.S.; El-Kasheif, M.A.; Ibrahim, S.A. and Authman, M. (2013). Effect of water pollution in ElRahawy drainage canal on hematology and organs of freshwater fish. World Appl. Sci. J., 21: 329-341.

Gabriel, U., Ezeri, G., Opabunmi, O., 2004. Influence of sex, source, health status and acclimation on the haematology of Clarias gariepinus (Burch, 1822). African Journal of Biotechnology 3.

Grosell, M. and McDonald, M.; Walsh, P. and Wood, C. (2004). Effects of prolonged copper exposure in the marine gulf toadfish (Opsanus beta) II: copper accumulation, drinking rate and $\mathrm{Na}+\mathrm{K}+-\mathrm{ATPase}$ activity in osmoregulatory tissues. Aquat. Toxicol., 68: 263-275.

Harabawy, A.S. and Ibrahim, A.T.A. (2014). Sublethal toxicity of carbofuran pesticide on the African catfish Clarias gariepinus (Burchell, 1822): hematological, biochemical and cytogenetic response. Ecotoxicol. and Environ. Safety, 103: 61-67.

Joshp, P.; Bose, M. and Harish, D. (2002). Changes in certain haematological parameters in a siluroid cat fish Clarias batrachus (Linn) exposed to cadmium chloride. Pollut. Res., 21: 129-131.

Kamunde, C.; Grosell, M.; Higgs, D. and Wood, C.M. (2002). Copper metabolism in actively growing rainbow trout (Oncorhynchus mykiss): interactions between dietary and waterborne copper uptake. J. Exper. Biol. 205: 279290.

Karaytug, S.; Karayakar, F.; Ciftci, N.; Cicik, B.; Ay, O. and Erdem, C. (2010). Effects of cadmium on sera glucose and cortisol levels in Clarias gariepinus (Burchell, 1822). J. Animal and Veterinary Advances, 9: 2159-2162.

Klinck, J.; Green, W.; Mirza, R.; Nadella, S.; Chowdhury, M.; Wood, C. and Pyle, G. (2007). Branchial cadmium and copper binding and intestinal cadmium uptake in wild yellow perch (Perca flavescens) from clean and metal-contaminated lakes. Aquat. Toxicol. 84: 198-207.

Kori-Siakpere, O.; Ake, J. and Avworo, U. (2006). Sublethal effects of cadmium on some selected haematological parameters of Heteroclarias (a hybrid of Heterobranchus bidorsalis and Clarias gariepinus). Int. J. Zool. Res., 2: 77-83.

Kumar, K. (2016). A review of heavy metals toxicological studies on mangur (Clarias batrachus) Fish. Int. J. Engineering and Management Res., (IJEMR) 6, 577-583. 


\section{Effects of cadmium on some haematological and biochemical parameters of Clarias graiepinus}

Liu, H.; Wang, W.; Zhang, J. and Wang, X. (2006). Effects of copper and its ethylene diamine tetraacetate complex on the antioxidant defenses of the goldfish, Carassius auratus. Ecotoxicol. and Environ. Safety, 65: 350-354.

Monteiro, S.M.; Mancera, J.M.; Fontaínhas-Fernandes, A. and Sousa, M. (2005). Copper induced alterations of biochemical parameters in the gill and plasma of Oreochromis niloticus. Comparative Biochemistry and Physiology Part C: Toxicology \& Pharmacology 141, 375-383.

Osman, A.G. and Kloas, W. (2010). Water quality and heavy metal monitoring in water, sediments, and tissues of the African catfish Clarias gariepinus (Burchell, 1822) from the river Nile, Egypt. J. Environ. Protection, 1: 389-400.

Patra, R.W.; Chapman, J.C.; Lim, R.P.; Gehrke, P.C. and Sunderam, R.M. (2015). Interactions between water temperature and contaminant toxicity to freshwater fish. Environ. Toxicol. Chem., 34: 1809-1817.

Perez, M. and Wallace, W. (2004). Differences in prey capture in grass shrimp, Palaemonetes pugio, collected along an environmental impact gradient. Arch. Environ. Contam. Toxicol., 46: 81-89.

Persch, T.S.P., Weimer, R.N., Freitas, B.S., Oliveira, G.T., 2017. Metabolic parameters and oxidative balance in juvenile Rhamdia quelen exposed to rice paddy herbicides: Roundup $®$, Primoleo®, and Facet ${ }^{\circledR}$. Chemosphere 174, 98-109.

Qu, R., Wang, X., Wang, Z., Wei, Z., Wang, L., 2014. Metal accumulation and antioxidant defenses in the freshwater fish Carassius auratus in response to single and combined exposure to cadmium and hydroxylated multiwalled carbon nanotubes. Journal of hazardous materials 275, 89-98.

Rubio, I., Martinez-Madrid, M., MéndezFernández, L., Galarza, A., Rodriguez, P., 2016. Heavy metal concentration in feathers of Little Egret (Egretta garzetta) nestlings in three coastal breeding colonies in Spain. Ecotoxicology 25, 30-40.

Samuel, P.O., Adakole, J.A., Suleiman, B., 2017. Histopathological alterations in kidney and liver of Clarias gariepinus (burchell, 1822) studied in river galma, Nigeria. Applied Scientific Reports 4, 1.

Sharma, J., Langer, S., 2014. Effect of manganese on haematological parameters of fish, Garra gotyla gotyla. Journal of Entomology and Zoology Studies 2, 77-81.

Sindhe, V.; Veeresh, M. and Kulkarni, R. (2002). Ovarian changes in response to heavy metal exposure to the fish, Notopterus notopterus (Pallas). J. Environ. Biol., 23: 137141.

Soegianto, A.; Moehammadi, N.; Irawan, B.; Affandi, M. and Hamami, M. (2010). Mercury concentrations in edible species harvested from Gresik coast, Indonesia and its health risk assessment. Cahiers de Biologie Marine, 51: 1.

Srivastava, N.; Kaushik, N. and Gupta, P. (2002). Zinc induced changes in the liver and muscle of fish Channa punctatus(Bloch). J. Ecophysiol. and Occupational Health, 2: $197-$ 204.

Szebedinszky, C.; McGeer, J.C.; McDonald, D.G. and Wood, C.M. (2001). Effects of chronic Cd exposure via the diet or water on internal organ-specific distribution and subsequent gill $\mathrm{Cd}$ uptake kinetics in juvenile rainbow trout (Oncorhynchus mykiss). Environ. Toxicol. and Chem., 20: 597-607. 


\section{Naglaa F. Elarabany et al.}

Zikić, R.; Stajn, A.; Pavlović, S.; Ognjanović, B. and Saićić, Z. (2001). Activities of superoxide dismutase and catalase in erythrocytes and plasma transaminases of goldfish
(Carassius auratus gibelio Bloch.) exposed to cadmium. Physiological research / Academia Scientiarum Bohemoslovaca 50: 105-111.

\section{تأثيرات الكادميوم على بعض المعايير الدموية والبيوكيميائية لسمك القرموط الأفريقي، Clarias graiepinus}

$$
\begin{aligned}
& \text { نجلاء العرباني 1ومحمد بهنساوي } 1 \text { ومني الفاخري } 291
\end{aligned}
$$

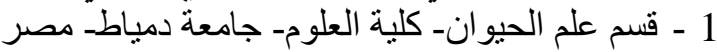

$$
\begin{aligned}
& 2 \text { - قسم علوم الحياة_ كلية العلوم- جامعة سبها- ليبيا }
\end{aligned}
$$

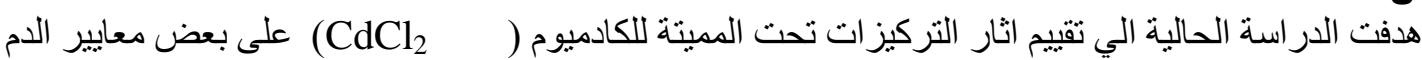

المستخلص

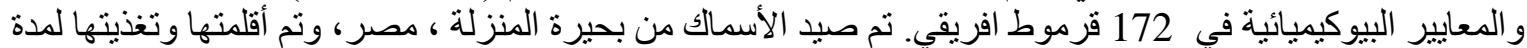

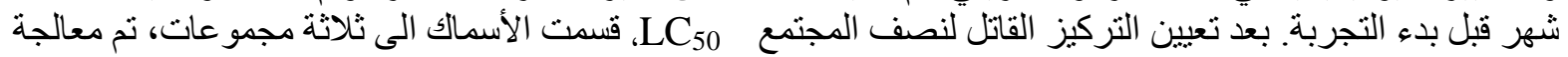

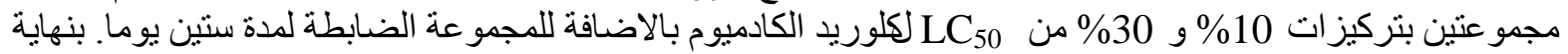

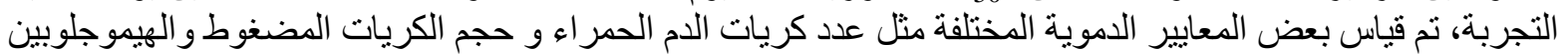

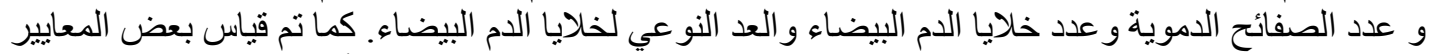

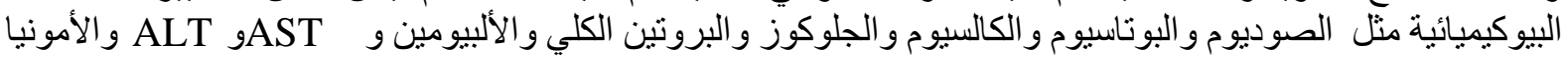

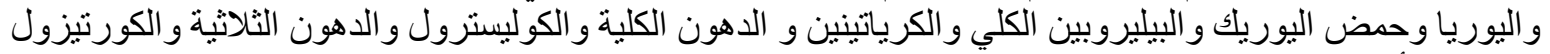

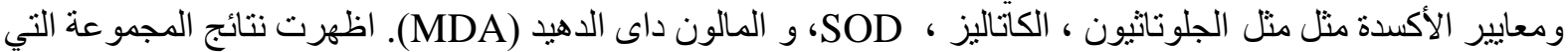

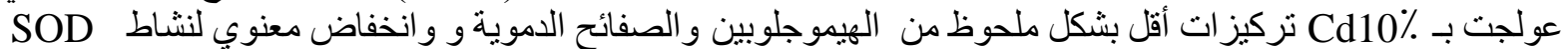

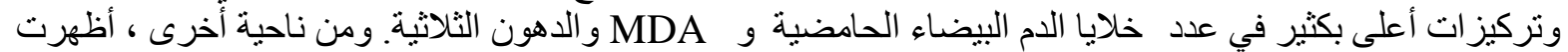

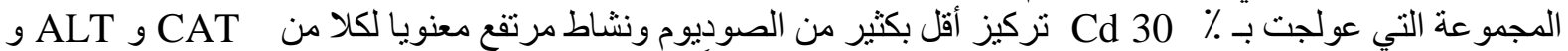

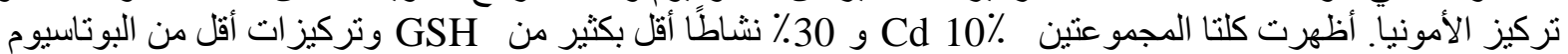

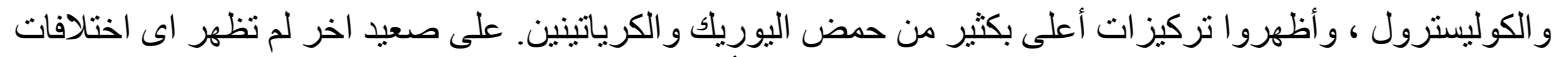

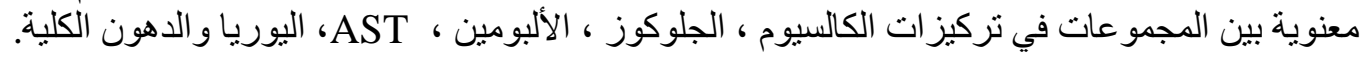

